\title{
Successful EUS-guided ethanol ablation of insulinoma, four-year follow-up. Case report and literature review
}

\author{
Skuteczna alkoholowa ablacja guza insulinowego trzustki, obserwacja 4-letnia. \\ Opis przypadku i przegląd literatury
}

\section{Krzysztof Dąbkowski', Paula Gajewska', Kamila Walter', Magdalena Londzin-Olesik², Andrzej Białek', Elżbieta Andrysiak-Mamos ${ }^{3}$, Beata Kos-Kudła ${ }^{2}$, Teresa Starzyńska ${ }^{1}$}

\author{
${ }^{1}$ Department of Gastroenterology, Pomeranian Medical University, Szczecin, Poland \\ ${ }^{2}$ Department of Endocrinology and Neuroendocrine Tumors, School of Medicine with the Division of Dentistry in Zabrze, Medical \\ University of Silesia, Katowice, Poland \\ ${ }^{3}$ Department of Endocrinology, Metabolic and Internal Diseases, Pomeranian Medical University, Szczecin, Poland
}

\begin{abstract}
Introduction: EUS-guided ethanol ablation of insulinoma is a new method of treatment of this neuroendocrine tumour. Ablation is recommended in patients who are poor surgical candidates or refuse surgery. We present a case of an 81-year-old female with symptomatic insulinoma, treated successfully with EUS-guided alcoholic ablation, along with a literature review including 28 other previously described cases. The effectiveness, safety of the therapy, and technical procedure-related issues are summarised. To the best of our knowledge, this is the first described case of successful insulinoma EUS- guided ablation in Poland.

Material and methods: We searched the PubMed/Medline database to identify cases of EUS-guided alcoholic ablation. Our analysis included 14 articles (case reports or case series), with a total of 27 patients and 31 tumours described, published before February 2017. Results: The described tumours were relatively small (mean $13 \mathrm{~mm}$ ), and the most common location was pancreatic head. The mean ethanol volume injected to the tumour was $1.8 \mathrm{ml}$ and the concentration of infused alcohol varied from $95 \%$ to $98 \%$.Side effects were observed in six cases; apart from one, they were mild and self-limiting. There was only one severe adverse event, treated conservatively with success. The median follow-up was 14.4 months (2-55 months). In all described cases ablation led to improvement of the symptoms and normalisation of glycaemia. Conclusions: The EUS-guided alcoholic ablation of insulinoma is a safe and effective method of treatment in patients who are poor surgical candidates and/or refuse surgery. The adverse effects are rare and mild and were observed when the volume of injected ethanol was equal to or above $3.0 \mathrm{ml}$. However, the data is limited, the follow-up is relatively short, and prospective studies are needed to confirm the long-term effects of treatment. The study shows also that there are important procedural differences (concentration and volume of alcohol, needle gauge, number of sessions) between the endoscopists, which should be specified. (Endokrynol Pol 2017; 68 (4): 472-479) Key words: insulinoma, alcoholic ablation, EUS
\end{abstract}

\section{Streszczenie}

Wstęp: Przedstawiono 81-letnią chorą z objawowym guzem insulinowym głowy trzustki. Pacjentka, z uwagi na liczne choroby współistniejące, została zdyskwalifikowana z leczenia chirurgicznego. Leczona diazoksydem, ciągłymi wlewami z glukozy, analogami somatostatyny bez istotnej poprawy(obserwowano działania niepożądane). Następnie pod kontrolą EUS wykonano alkoholową ablację zmiany. Nie obserwowano powikłań. Odstawiono diazoksyd, obserwując normalizacje glikemii. Pacjentka w 4-letniej obserwacji pozostaje bez objawów klinicznych hipoglikemii. Według naszej wiedzy jest to pierwszy opisany przypadek skutecznej alkoholowej ablacji guza insulinowego w Polsce. W pracy przeprowadzono przegląd literatury i podsumowanie wcześniej przeprowadzonych i opisanych zabiegów alkoholowej ablacji guzów insulinowych, ze szczególnym naciskiem na skuteczność i bezpieczeństwo, czas obserwacji po leczeniu i szczegóły techniczne przeprowadzenia procedury.

Materiał i metody: Przeszukano bazę Pub Med/Medline, aby zidentyfikować opisane przypadki alkoholowej ablacji guza insulinowego trzustki. Do analizy włączono 14 artykułów opublikowanych przed końcem lutego 2017, w których opisano łącznie 27 przypadków i 31 guzów insulinowych.

Wyniki: Opisane guzy były stosunkowo małymi zmianami (średnio $13 \mathrm{~mm}$ ), ich najczęstsza lokalizacją była głowa trzustki. Średnia objętość podawanego alkoholu to $1,8 \mathrm{ml}$, a stężenie wynosiło 95-98\%. Efekty uboczne obserwowano w 6 przypadkach, poza jednym były one łagodne i ustępowały samoistnie. Zaobserwowano tylko jedno poważne powikłanie leczone zachowawczo z sukcesem. Średni czas obserwacji pacjenta wyniósł 14,4 miesiąca (od 2 do 55 miesięcy). U wszystkich opisanych chorych ablacja doprowadziła do ustąpienia objawów i normalizacji glikemii. Wnioski: Alkoholowa ablacja guza insulinowego trzustki pod kontrolą EUS jest bezpieczną i skuteczną metoda leczenia tego guza u pacjentów z przeciwwskazaniami do zabiegu lub takich, którzy nie godzą się na zabieg. Większość powikłań ma charakter łagodny i były one obserwowane, gdy objętość podawanego do guza etanolu przekraczała 3,0 ml. Krótki czas obserwacji pacjentów i niewielka liczba opisanych przypadków, sprawiają że konieczne jest zaplanowanie badań prospektywnych, które mogłyby potwierdzić długoterminowe efekty leczenia. Analiza pokazuje również, że występują istotne różnice pomiędzy endoskopistami w zakresie sposobu przeprowadzenia samej procedury (stężenie i objętość alkoholu, rozmiar igły, liczba sesji). Powinno dążyć się do sprecyzowania sposobu jej wykonania. (Endokrynol Pol 2017; 68 (4): 472-479)

Słowa kluczowe: insulinoma, alkoholowa ablacja, EUS 
Table I. Hormonal assessment in an 81-year-old insulinoma patient before and after treatment (ablation) Table I. Ocena hormonalna 81-letniej pacjentki z cukrzyca przed i po leczeniu

\begin{tabular}{lllllllll}
\hline \multirow{2}{*}{ Time of assessment } & \multicolumn{2}{l}{ Glucose $(\mathbf{m g} / \mathrm{dl})$} & \multicolumn{2}{l}{ Insulin $(\mathbf{u U} / \mathbf{m l})$} & \multicolumn{2}{l}{ C-Peptide $(\mathbf{n g} / \mathbf{m l})$} & \multicolumn{2}{l}{ Chromogranin A (U/l) } \\
\cline { 2 - 9 } & Before & After & Before & After & Before & After & Before & After \\
\hline 6.00 & 29.00 & 83.00 & 33.31 & 4.90 & 4.79 & 2.20 & 146.00 & 12.00 \\
10.00 & 78.00 & 91.00 & 75.8 & & & & & \\
14.00 & 65.00 & 78.00 & & 6.30 & & & & \\
18.00 & 69.00 & 112.00 & & & & & & \\
22.00 & 37.00 & 96.00 & & 4.20 & 9.97 & 5.30 & & \\
\hline
\end{tabular}

Insulin (n. 2.7-10.4 uU/ml); C-Peptide (n. 0.78-5.19 ng/ml); Chromogranin A (n. 2-18 U/l)

Other markers of neuroendocrine neoplasm (NEN):

\begin{tabular}{llll}
\hline 5-HIAA I 24-h Urine & 5-HIAA II 24-h Urine & Serotonin & Gastrin \\
\hline $8.58 \mathrm{mg} / 24 \mathrm{~h}$ (n. 2-9) & $8.20 \mathrm{mg} / 24 \mathrm{~h}$ (n. 2-9) & $350 \mathrm{ng} / \mathrm{ml} \mathrm{(n.} \mathrm{40-400)}$ & $46.0 \mathrm{uU} / \mathrm{ml}$ (n. 28-185) \\
\hline
\end{tabular}

\section{Introduction}

Insulinoma is not only the most common functioning neuroendocrine pancreatic tumour but also the most common cause of endogenous hyperinsulinaemic hypoglycaemia [1]. The basic method of treatment remains surgery. However, especially in older individuals, it is related to significant risk of complications and death. Conservative treatment with use of diazoxide is not always effective, and the adverse effects are often observed [2]. Therefore, new methods of treatment are proposed with use of somatostatin analogues, mTOR inhibitor (everolimus), tyrosine kinase inhibitor (sunitinib), peptide receptor radionuclide therapy (PPRT), chemoembolisation, and radiofrequency or alcoholic ablation [3-11].

We present a patient with insulinoma, who because of age and coexisting comorbidities was disqualified from surgery. The patient was treated successfully with a new and promising method: EUS-guided alcoholic ablation. The patient remains free from symptoms after four-year observation. A review of the literature with special focus on the effectiveness/safety of therapy and technical procedure-related issues was performed.

\section{Case report}

An 81-year-old female patient with a history of insulinoma was admitted to the department of gastroenterology for endoscopic alcoholic ablation of the lesion.

The patient's main complaints were repetitive dizziness, loss of consciousness, and also numbness of lips and tongue for the last five years. The diagnosis of insulinoma was made in the endocrinology department. The fasting test was positive and revealed increased insulin, $C$ peptide, and decreased glucose level. There was no evidence of MEN1 syndrome, and pituitary

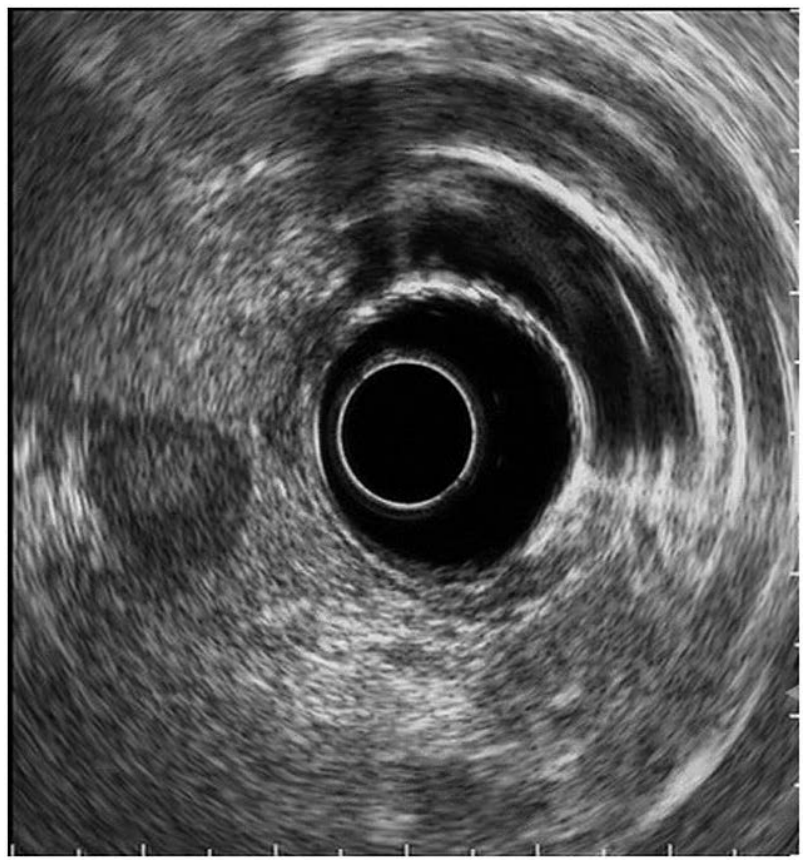

Figure 1. EUS showing hypoechoic $15 \mathrm{~mm}$ tumour located in the pancreatic head

Rycina 1. Hypoechogenny guz głowy trzustki o wymiarach $15 \mathrm{~mm}$ w ultrasonografii endoskopowej

and parathyroid hormone tests were all within normal limits. Laboratory tests showed elevation of chromogranin A concentration. Table I presents the results of the patient's hormonal assessments.

Computed tomography (CT), showed a small tumour measuring $15 \times 10 \mathrm{~mm}$ located in the pancreatic head, and a positron emission tomography (PET) scan with use of somatostatin analogues (labelled with gallium-68) demonstrated increased metabolic activity in the same area (Fig. 2). There was no evidence of metastases. The patient was disqualified from surgery because of age and 


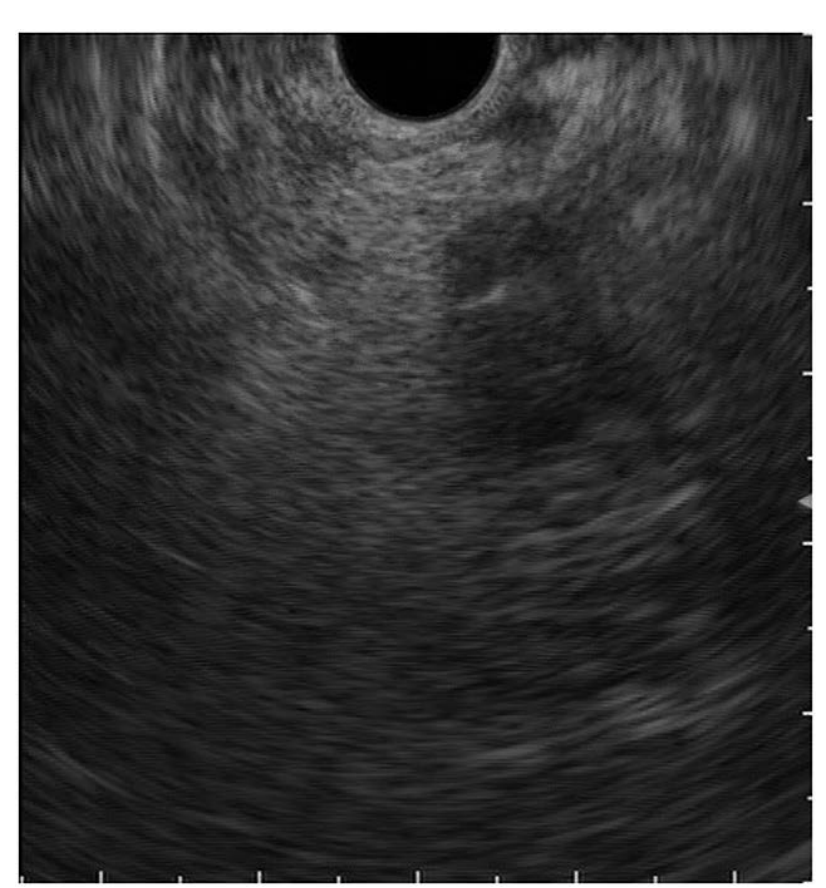

Figure 2. EUS-guided ablation. The needle is seen within the tumour

Rycina 2. Ablacja endoskopowa. Wprowadzenie igty do guza

coexisting comorbidities (hypertension, coronary heart disease, and chronic obstructive pulmonary disease). Thereafter, she was given a recommendation to start therapy with diazoxide. However, adverse effects were observed (diffuse oedema) and it did not lead to improvement of symptoms or normalisation of glucose levels.

We decided to perform EUS-guided alcoholic ablation of the tumour as an alternative to surgical resection. EUS demonstrated a hypoechoic $15 \mathrm{~mm}$ lesion located in the pancreatic head (Fig. 1). During the examination the puncture, using a 22G-needle was performed and $1 \mathrm{ml}$ $96 \%$ ethanol was injected into the lesion (Fig. 2). We observed hyperechoic blush within the tumour (Fig. 3). The levels of glycaemia improved (Table I); however, we still observed hypoglycaemia-related symptoms. Thereafter, the same procedure was repeated after seven days with injection of $2 \mathrm{ml}$ of alcohol. There were no procedurerelated complications. The treatment with diazoxide was discontinued, and normalisation of glycaemia levels were observed during the same hospital stay. Table I presents the patients glycaemic profile before and after alcoholic ablation. The patient is free from symptoms of hypoglycaemia in four-year observation.

\section{Database research}

We searched the PubMed/Medline database to identify cases of EUS-guided alcoholic ablation. Our analysis included 14 relevant articles (case or case series, our

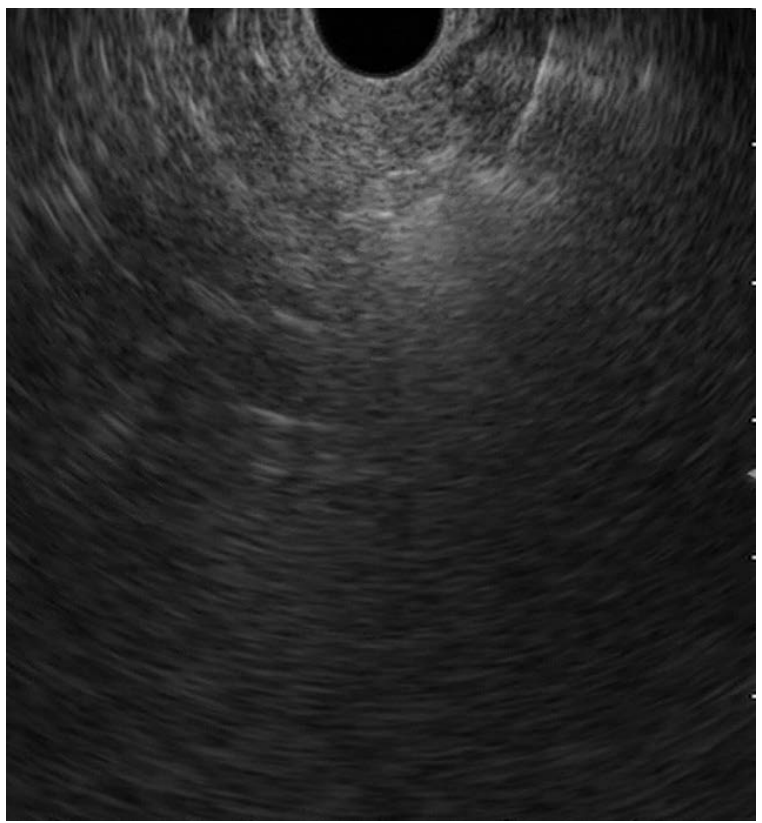

Figure 3. EUS-guided ablation. Hyperechoic blush is seen when the ethanol is injected

Rycina 3. Ablacja endoskopowa. Hiperechogeniczne ognisko widoczne podczas wstrzyknięcia etanolu

case) with total of 27 patients and 31 tumours (two patients with multiple lesions) published before February 2017. The search terms were "insulinoma ablation" and "endoscopic ultrasound guided ethanol ablation of tumours". Twelve articles were written in English and two in other languages (Hungarian, Danish). We obtained missing information via e-mail directly from the authors.

\section{Results}

The described tumours were relatively small (mean $13 \pm 5.0 \mathrm{~mm}$ ) and the most common location (59.3\% of the tumours) was pancreatic head. Most of the patients were females $(60.9 \%)$ and the mean age of the patients was $61 \pm 22.6$ years (range 26-99 years). MEN 1 syndrome was present in four patients (14.9\%), and most of the tumours were sporadic $(85.2 \%)$. The mean ethanol volume and concentration injected to the tumour was $1.8 \mathrm{ml}$ (range $0.2-8 \mathrm{ml}$ ), and the concentration of infused alcohol varied from 95 to $98 \%$. The side effects were observed in six cases, they were mild, self-limiting, and were observed when the volume of ethanol was equal to or above $3.0 \mathrm{ml}$. There was only one severe adverse event: bleeding from a duodenal ulcer (in a puncture site), treated conservatively with success. The median follow-up was 14.4 months. In all described cases, ablation led to improvement of the symptoms and normalisation 
Table II. Clinical characteristics of patients

Table II. Charakterystyka kliniczna pacjentów

\begin{tabular}{|c|c|c|c|c|c|}
\hline Authors/Journal & $\begin{array}{l}\text { Number of } \\
\text { cases }\end{array}$ & Age & Sex & MEN1 & Size $(\mathrm{mm}) /$ location \\
\hline Dabkowski K et al. & $\mathrm{n}=1$ & 81 & $\mathrm{~F}$ & - & 15/pancreatic head \\
\hline Burghardt K et al. Diabetes Metab. 2017 [36] & $\mathrm{n}=1$ & 65 & W & - & 16/head/body \\
\hline Luo Y et al. Clin Nucl Med. 2017 [37] & $\mathrm{n}=1$ & 32 & $\mathrm{M}$ & - & 27/head \\
\hline Trikudanthan G et al. Clin Endosc. 2016 [25] & $\mathrm{n}=1$ & 66 & $\mathrm{M}$ & - & 14/head \\
\hline \multirow[t]{3}{*}{ Paik WH et al. Medicine (Baltimore) 2016 [28] } & & $1 / 99$ & $1 / \mathrm{M}$ & - & 1/9/head \\
\hline & $\mathrm{n}=3$ & $2 / 20$ & $2 / \mathrm{M}$ & - & 2/11/head \\
\hline & & $3 / 32$ & $3 / \mathrm{M}$ & - & 3/14/head \\
\hline \multirow[t]{5}{*}{ Park DH et al. Clin Endosc. 2015 [38] } & & 66 & $\mathrm{~F}$ & _- & 13/head \\
\hline & $\mathrm{n}=2$ & 27 & $\mathrm{~F}$ & + & Multiple lesions: \\
\hline & & & & & 17/head \\
\hline & & & & & 10/body \\
\hline & & & & & 10/tail \\
\hline \multirow[t]{2}{*}{ Yang D et al. Gastrointest Endosc. 2015 [27] } & & 59 & $\mathrm{~N} / \mathrm{A}$ & 3 sporadic & $\mathrm{N} / \mathrm{A}$ \\
\hline & $\mathrm{n}=4$ & $(47-86)$ & & 1MEN & \\
\hline \multirow[t]{4}{*}{ Qin SY et al. Medicine (Baltimore). 2014 [22] } & & $1 / 48$ & $\mathrm{~F}$ & & 1/10/head \\
\hline & & $2 / 56$ & $\mathrm{~F}$ & & 2/5.4/head \\
\hline & $\mathrm{n}=4$ & $3 / 56$ & M & & 3/11.8/head/body \\
\hline & & $4 / 66$ & $\mathrm{~F}$ & & 4/10/body \\
\hline Bor R et al. Orv Hetil. 2014 [18] & $\mathrm{n}=1$ & 83 & $\mathrm{~F}$ & - & $\begin{array}{l}\text { 11/junction of body } \\
\text { and tail }\end{array}$ \\
\hline \multirow[t]{4}{*}{ Lee MJ et al. Intern Med J. 2013 [20] } & $\mathrm{n}=1$ & 26 & $\mathrm{~F}$ & + & Multiple lesions \\
\hline & & & & & 17/head \\
\hline & & & & & $9 /$ body \\
\hline & & & & & 7/tail \\
\hline \multirow[t]{5}{*}{ Levy MJ et al. Gastrointest Endosc. 2012 [21] } & & 72 & $\mathrm{~F}$ & - & 1/18/head \\
\hline & $\mathrm{n}=5$ & 82 & M & - & 2/20/tail \\
\hline & & 80 & $\mathrm{~F}$ & - & $3 / 21 /$ body \\
\hline & & 57 & $\mathrm{~F}$ & - & 4/8/head \\
\hline & & 34 & M & + & 5/16/head \\
\hline Schnack C et al. Ugeskr Laeger 2012 [24] & $\mathrm{n}=1$ & 89 & M & - & 6/body \\
\hline Vleegar FP et al. Endoscopy 2011 [26] & $\mathrm{n}=1$ & 82 & $\mathrm{~F}$ & - & 9.5/body \\
\hline Deprez PH et al. 2008 [19] & $\mathrm{n}=1$ & 78 & $\mathrm{~F}$ & - & 17/head \\
\hline $\begin{array}{l}\text { Jürgensen C et al. Gastrointest EndosC } \\
2006 \text { [17] }\end{array}$ & $\mathrm{n}=1$ & 78 & $\mathrm{~F}$ & - & 13/body \\
\hline
\end{tabular}

of glycaemia levels. The clinical characteristics of the patients and procedure-related issues are presented in Table II and III. A summary of the results is presented in Table IV.

\section{Discussion}

Insulinomas are rare and relatively small neuroendocrine tumours mostly located in the pancreas [1]. They manifest typically with recurrent episodes of hypoglycaemia while fasting and exercising [3]. However, there is a group of patients (up to $18 \%$ ) whose symptoms appear postprandially [3, 12].The treatment of choice is surgical resection of the tumour or symptomatic treatment (small frequent meals and diazoxide) in patients who do not qualify for the surgery (i.e. poor general condition, metastatic disease, or patient's refusal of surgical procedure) [3]. The ENETS consensus guidelines conclude that in all patients with insulinomas (excluding those with metastatic disease) 
Table III. Procedure-related issues

Table III. Kwestie proceduralne

\begin{tabular}{|c|c|c|c|c|c|c|}
\hline Authors/Journal & $\begin{array}{l}\text { No. of } \\
\text { sessions }\end{array}$ & $\begin{array}{l}\text { Volume of ethanol } \\
\text { (ml) }\end{array}$ & $\begin{array}{l}\text { Concentration } \\
(\%)\end{array}$ & $\begin{array}{l}\text { Needle } \\
\text { (G) }\end{array}$ & Adverse effects & $\begin{array}{l}\text { Follow-up } \\
\text { (months) }\end{array}$ \\
\hline \multirow[t]{2}{*}{ Dabkowski K et al. } & 2 & I(session)-1 & 96 & 22 & No & 36 \\
\hline & & II-2 & & & & \\
\hline Burghardt K et al. [36] & 1 & 1 & $96 \%$ & N/A & No & 1.5 \\
\hline Luo Y et al. [37] & 1 & 1.5 & 99 & 19 & Abd. pain & 4 \\
\hline Trikudanthan G et al. [25] & 1 & 1 & 99 & N/A & No & 1.5 \\
\hline \multirow[t]{3}{*}{ Paik WH et al. [28] } & & $1 / 1.2$ & 99 & 22 & 1/No & $5.4-55.3$ \\
\hline & 1 & $2 / 2.5$ & & & 2/No & (mean 16.5) \\
\hline & & $3 / 3.0$ & & & 3/Abd. pain & \\
\hline \multirow[t]{4}{*}{ Park DH et al. [38] } & 2 & $1 / \mathrm{I}-2.6$ & 99 & 22 & No & 12 \\
\hline & & II-3.8 & & & & \\
\hline & 1 & 2/1.0/head, body & 99 & 22 & No & 24 \\
\hline & & $1.2 /$ tail & 99 & 22 & & \\
\hline \multirow[t]{2}{*}{ Yang D et al. [27] } & & $05-7.0$ & 98 & 22 & No & $2-30$ \\
\hline & & (mean 3.1) & & & & (mean 17.3) \\
\hline \multirow[t]{5}{*}{ Qin SY et al. [22] } & & Aliquots blush & 95 & 25 & & \\
\hline & & $1 / 0.5$ & & & & $1 / 6$ \\
\hline & 1 & $2 / 0.25$ & & & No & $2 / 4$ \\
\hline & & $3 / 0.5$ & & & & $3 / 5$ \\
\hline & & $4 / 0.3$ & & & & $4 / 2$ \\
\hline Bor R et al. [18] & 1 & 3 & 95 & 22 & Abd. pain & 36 \\
\hline \multirow[t]{2}{*}{ Lee MJ et al. [20] } & 1 & $1 /$ head, body & 95 & 22 & No & 12 \\
\hline & & 2/tail & & & & \\
\hline \multirow[t]{13}{*}{ Levy MJ et al. [21] } & 2 or & $1 / \mathrm{I}-0.12$ & 95 & 22 & No & 13 \\
\hline & 3 & II-0.38 & & & & \\
\hline & & III-0.12 & & & & \\
\hline & & $2 / 1-0.12$ & 98 & 25 & & 13 \\
\hline & & II-0.25 & & & & \\
\hline & & $3 / 1-0.95$ & 98 & $1-25$ & & 12 \\
\hline & & II-0.28 & & & & \\
\hline & & $4 / 1-3.0$ & 98 & II-22 & & 38 \\
\hline & & II-1.5 & & & & \\
\hline & & $5 / 1-0.7$ & 99 & 22 & & 5 \\
\hline & & II-1.0 & & & & \\
\hline & & $0.12-3.0 \mathrm{ml}$ & & & & $5-38$ \\
\hline & & (mean 0.8 ml) & & 22 & & (median 13) \\
\hline Schnack C et al. [24] & 1 & 3.5 & 98 & N/A & Mild pancreatitis & 2 \\
\hline Vleegar FP et al. [26] & 1 & 0.3 & 96 & 25 & No & 6 \\
\hline Deprez PH et al. [19] & 1 & 3.5 & 98 & 21.25 & $\begin{array}{l}\uparrow \text { pancreatic } \\
\text { enzymes, } \\
\text { hematoma, } \\
\text { duodenal ulceration } \\
\text { (Forrest 2a) and } \\
\text { bleeding }\end{array}$ & 24 \\
\hline Jürgensen C et al. [17] & 1 & 8 & 95 & & Mild pancreatitis & 34 \\
\hline
\end{tabular}


Table IV. Summary of patients' characteristics and procedurerelated issues

Tabela IV. Charakterystyka pacjentów $i$ kwestie proceduralne

\begin{tabular}{ll}
\hline Number of patients & $\mathbf{2 7}$ \\
\hline Sporadic/MEN1 & $23 / 4$ \\
& $(85.2 \%) /(14.8 \%)$ \\
\hline Number of tumours & 31 (two patients with multiple lesions) \\
\hline Age (years) & 61 (mean) \pm 22.6 \\
& $(26-99)$ (range) \\
\hline Sex (F/M) & $14 / 9$ \\
& $(60.9 \%) /(39.1 \%)$ \\
& $($ information about 4 patients N/A) \\
\hline Size of tumour (mm) & $13 \pm 5$ \\
& $(5.4-27)$ \\
\hline Location (head/body/tail) & $16 / 8 / 3$ \\
& $(59.3 \%) /(29.6 \%) /(11.1 \%)$ \\
\hline Volume of ethanol (ml) & $1.8 \pm 1.8$ \\
& $(0.2-8)$ \\
\hline Concentration (\%) & $(95-99)$ \\
\hline Follow-up (months) & $14.4 \pm 14.6$ \\
\hline Adverse events & $(2-55$ months) \\
\hline Motal & $6(18.7 \%)$ \\
\hline & $4(12.5 \%)$ \\
\hline Severe & $1(3.1 \%)$ \\
\hline & $27 / 27(100 \%)$ \\
\hline
\end{tabular}

surgical exploration should be performed, and in patients with sporadic disease a laparoscopic approach is recommended [3].

Surgical treatment is associated with significant risk of complications, which limits its use, especially in older individuals with comorbidities [13]. The less invasive method of treatment is tumour enucleation, which is not always possible to perform. However, mortality, overall complication rates, and need of re-interventions are comparable between standard resections and enucleation, while the rate of fistula is even higher in the enucleation group [13, 14]. In contrast, the incidence of exocrine and endocrine insufficiency are significantly higher after Whipple's procedure [13].

In cases of inoperable disease, typically treatment with diazoxide is initiated. However, it is not always effective, and adverse effects (especially fluid retention and hirsutism) are often observed [2]. Recently, novel therapies with use of somatostatin analogues, everolimus, sunitinib, peptide receptor radionuclide therapy
(PPRT), chemoembolisation and radiofrequency and alcoholic ablation were proposed $[11,15,16]$.

EUS-guided ethanol ablation of pancreatic insulinoma is a novel method, first reported by the group of Jürgensen C. et al. [17]. The Medline database research shows 14 cases or case series of insulinoma EUS-guided ethanol ablation [17-27]. Moreover, there are also reports of alcoholic ablation of other pancreatic tumours of neuroendocrine and other origin (especially cystic pancreatic tumours) [28-30]. Some prospective studies are still in progress [29].

Database research shows not only safety but also efficacy of this procedure (Table II, IV). Most of the described tumours were small insulinomas with a mean diameter of $13 \mathrm{~mm}$. The volume of injected ethanol varied from 0.2 to $8 \mathrm{ml}$, and some authors decided for one session others for two. The concentrations of alcohol ranged from 95 to $99 \%$, and the needle gauge was between 19 and $25 \mathrm{G}$. These differences between the groups raise important questions about optimal procedural issues that are not yet established and about the effectiveness and safety of this treatment in larger tumours and in non-functioning tumours.

Yang D. et al. injected $98 \%$ ethanol in $0.1 \mathrm{ml}$ repeated samples until hyperechoic blush was seen in the tumour [27]. Quin S. et al. proposed a formula in which the volume of injected alcohol in round, regular tumours was half of the size of the lesion, while in oval and irregular tumours the volume of alcohol should be determined by adding the minor and major axis of the lesion [22]. They also reduced the dose of infused alcohol to a half or one third when the tumour was located near a vessel or pancreatic duct [22].

All of the patient's symptoms and their glycaemic profiles improved after the procedure. The longest follow-up was 55 months. In functioning tumours we can determine the effectiveness of the procedure clinically (improvement of symptoms) or by measuring the hormonal activity. In non-functioning tumours the issue of follow-up is more complex. Some authors performed follow-up EUS (also in insulinoma) and it revealed partial or total tumour size regression [17, $19,28]$. However, we are not able to predict long-term results and the risk of development of metastases and recurrence of the disease $[22,28,31,32]$.

The side effects were generally mild and self-limiting: mild acute pancreatitis, fever, abdominal pain [17, $18,22,28]$. Only one described event should be classified as severe-bleeding from duodenal ulcer (Forrest 2a) with haematoma, which was treated conservatively with proton pump inhibitor [19]. We noticed that the adverse events were observed only when the volume of injected alcohol was equal to or above $3.0 \mathrm{ml}$ (Table III). In our opinion, the strategy described by some authors 
in which ethanol is injected under the control of sight, in small aliquots $(0.1 \mathrm{ml})$ until the hyperechoic blush is seen within the tumour, is feasible, rational, and safe. The volume of alcohol injected to the small tumours (as those described) should not exceed $3.0 \mathrm{ml}$. This conclusion is supported by another severe complication of ablation (of non-functioning neuroendocrine tumour) reported by Paik et al. [28]. The injection of $5.0 \mathrm{ml}$ of alcohol with use of a multi-hole celiac plexus neurolysis needle $(\mathrm{CPN})$ resulted in acute pancreatitis and 36 days of hospital stay [28]. Therefore, the authors recommend use of a single-hole needle in the procedure [28]. A relation between the volume of injected ethanol and the adverse events was also noted by the authors of previously published cases and is amplified by our study [28].The risk of development of adverse events depends naturally on the experience of the endoscopist.

The concentrations of ethanol used in the procedure were between 95 and $99 \%$. There are sparse data about the use of lower concentrations of ethanol. Muscatiello et al. described the case of ablation of an endocrine tumour, in which a low concentration of alcohol $(40 \%)$ was used. The second session of the procedure ended up with ethanol effusion during needle retraction, which resulted in pancreatic necrosis, treated with laparoscopic necrosectomy [33].

The described tumours were relatively small and we do not know much about the safety and efficacy of ethanol ablation in larger tumours. Mathers B.W. et al. reported successful ablation of large metastatic carcinoid lesion $(11.4 \mathrm{~cm})$ located in liver hilum. The procedure lead to a $36 \%$ reduction of tumour size, improvement of pain, and decrease of chromogranin level [34].

In our patient, we decided to perform two sessions of ablation. The first procedure did not lead to improvement, the patient still suffered from hypoglycaemiarelated symptoms, and the levels of glucose in blood were still low. Moreover, our previous, unpublished observations showed that one session of ablation was not effective (in our previous case, the patient did not agree to the second session and she still suffered from hypoglycaemia). In our opinion, the decision to perform a subsequent procedure should depend on the presence of clinical symptoms. Moreover, while deciding on the second session, endoscopists should take into account the risk of adverse events related to EUS-FNA [35].

\section{Conclusions}

EUS-guided alcoholic ablation of insulinoma is safe and effective method of treatment (technical success in 100\%) and is indicated in patients who are poor surgical candidates and/or refuse surgery. The adverse effects are mild and were observed when the volume of injected ethanol was equal to or above $3.0 \mathrm{ml}$. However, the data is limited, the follow-up is relatively short, and prospective studies are needed to confirm the longterm effects of treatment. Moreover, we are not able to predict long-term outcomes and the risk of recurrence and development of metastases. The study shows also that there are important procedural differences (concentration and volume of alcohol, number of sessions) between the endoscopists, which should be specified.

\section{References}

1. Kos-Kudła B, Rosiek V, Borowska M. Pancreatic neuroendocrine neoplasms - management guidelines (recommended by the Polish Network of Neuroendocrine Tumours). Endokrynol Pol. 2017; 68(2): 169-198.

2. Gill GV, Rauf O, MacFarlane IA. Diazoxide treatment for insulinoma: a national UK survey. Postgrad Med J. 1997; 73(864): 640-641, indexed in Pubmed: 9497974.

3. Falconi M, Eriksson B, Kaltsas G, et al. Vienna Consensus Conference participants. ENETS Consensus Guidelines Update for the Management of Patients with Functional Pancreatic Neuroendocrine Tumors and Non-Functional Pancreatic Neuroendocrine Tumors. Neuroendocrinology. 2016; 103(2): 153-171, doi: $\underline{10.1159 / 000443171}$, indexed in Pubmed: 26742109.

4. Jawiarczyk A, Bolanowski M, Syrycka J, et al. Effective therapy of insulinoma by using long-acting somatostatin analogue. A case report and literature review. Exp Clin Endocrinol Diabetes. 2012; 120(2): 68-72, doi: 10.1055/s-0031-1287792, indexed in Pubmed: 22187292.

5. Bernard V, Lombard-Bohas C, Taquet MC, et al. French Group of Endocrine Tumors. Efficacy of everolimus in patients with metastatic insulinoma and refractory hypoglycemia. Eur J Endocrinol. 2013; 168(5): 665-674, doi: 10.1530/EJE-12-1101, indexed in Pubmed: 23392213.

6. Chen J, Wang C, Han J, et al. Therapeutic effect of sunitinib malate and its influence on blood glucose concentrations in a patient with metastatic insulinoma. Expert Rev Anticancer Ther. 2013; 13(6): 737-743, doi: 10.1586/era.13.45, indexed in Pubmed: 23573816.

7. van Schaik E, van Vliet EI, Feelders RA, et al. Improved control of severe hypoglycemia in patients with malignant insulinomas by peptide receptor radionuclide therapy. J Clin Endocrinol Metab. 2011; 96(11): 3381-3389, doi: 10.1210/jc.2011-1563, indexed in Pubmed: 21917872.

8. Maiza JC, Vezzosi D, Grunenwald S, et al. Treatment with somatostatin analogs and chemoembolization of liver metastases for severe hypoglycemia in malignant insulinomas. J Endocrinol Invest. 2011; 34(9): e253-e258, doi: 10.3275/7762, indexed in Pubmed: 21623151.

9. de Herder WW, van Schaik E, Kwekkeboom D, et al. New therapeutic options for metastatic malignant insulinomas. Clin Endocrinol (Oxf). 2011; 75(3): 277-284, doi: 10.1111/j.1365-2265.2011.04145.x, indexed in Pubmed: 21649688 .

10. Łabuzek K, Duda K, Cholewa H, et al. [The newest perspectives on diagnostic methods and treatment of insulinoma]. Wiad Lek. 2014; 67(2 Pt 1): 85-92, indexed in Pubmed: 25764782.

11. Waung JA, Todd JF, Keane MG, et al. Successful management of a sporadic pancreatic insulinoma by endoscopic ultrasound-guided radiofrequency ablation. Endoscopy. 2016; 48 Suppl 1: E144-E145, doi: 10.1055/s-0042-104650, indexed in Pubmed: 27081874.

12. Toaiari M, Davì MV, Dalle Carbonare L, et al. Presentation, diagnostic features and glucose handling in a monocentric series of insulinomas. J Endocrinol Invest. 2013; 36(9): 753-758, doi: 10.3275/8942, indexed in Pubmed: 23608735.

13. Jilesen APJ, van Eijck CHJ, Busch ORC, et al. Postoperative Outcomes of Enucleation and Standard Resections in Patients with a Pancreatic Neuroendocrine Tumor. World J Surg. 2016; 40(3): 715-728, doi: $10.1007 /$ s00268-015-3341-9, indexed in Pubmed: 26608956.

14. Chua TC, Yang TX, Gill AJ, et al. Systematic Review and Meta-Analysis of Enucleation Versus Standardized Resection for Small Pancreatic Lesions. Ann Surg Oncol. 2016; 23(2): 592-599, doi: 10.1245/s10434-015-4826-3, indexed in Pubmed: 26307231.

15. Ito T, Lee L, Jensen RT. Treatment of symptomatic neuroendocrine tumor syndromes: recent advances and controversies. Expert Opin Pharmacother. 2016; 17(16): 2191-2205, doi: 10.1080/14656566.2016.1236916, indexed in Pubmed: 27635672.

16. Scott A, Hinwood D, Donnelly R. Radio-frequency ablation for symptom control in a patient with metastatic pancreatic insulinoma. Clin Endocrinol (Oxf). 2002; 56(4): 557-559, indexed in Pubmed: 11966750.

17. Jürgensen C, Schuppan D, Neser F, et al. EUS-guided alcohol ablation of an insulinoma. Gastrointest Endosc. 2006; 63(7): 1059-1062, doi: 10.1016/j. gie.2005.10.034, indexed in Pubmed: 16733126. 
18. Bor R, Farkas K, Bálint A, et al. [Endoscopic ultrasound-guided ethanol ablation: an alternative option for the treatment of pancreatic insulinoma]. Orv Hetil. 2014; 155(41): 1647-1651, doi: 10.1556/OH.2014.30012 indexed in Pubmed: 25282110.

19. Deprez PH, Claessens A, Borbath I, et al. Successful endoscopic ultrasound-guided ethanol ablation of a sporadic insulinoma. Acta Gastroenterol Belg. 2008; 71(3): 333-337, indexed in Pubmed: 19198582.

20. Lee MJ, Jung CH, Jang JE, et al. Successful endoscopic ultrasound-guided ethanol ablation of multiple insulinomas accompanied with multiple endocrine neoplasia type 1. Intern Med J. 2013; 43(8): 948-950, doi: 10.1111/imj.12208, indexed in Pubmed: 23919339.

21. Levy MJ, Thompson GB, Topazian MD, et al. US-guided ethanol ablation of insulinomas: a new treatment option. Gastrointest Endosc. 2012; 75(1): 200-206, doi: 10.1016/j.gie.2011.09.019, indexed in Pubmed: 22078104.

22. Qin Sy, Lu Xp, Jiang Hx. EUS-guided ethanol ablation of insulinomas: case series and literature review. Medicine (Baltimore). 2014; 93(14): 85, doi: 10.1097/MD.0000000000000085, indexed in Pubmed: 25255024

23. Bor R, Farkas K, Bálint A et al. Endoscopic ultrasound-guided fine needle injection: alternative option for the treatment of pancreatic insulinoma. Case report. http://dxdoiorg/101556/OH201430012.

24. Schnack C, Hansen C $\varnothing$, Beck-Nielsen $\mathrm{H}$, et al. [Treatment of insulinomas with alcoholic ablation]. Ugeskr Laeger. 2012; 174(8): 501-502, indexed in Pubmed: 22348674.

25. Trikudanathan G, Mallery SJ, Amateau SK. Successful Endoscopic Ultrasound-Guided Alcohol Ablation of Sporadic Insulinoma Using Three-Dimensional Targeting (with Video). Clin Endosc. 2016; 49(4): 399-401, doi: 10.5946/ce.2015.144, indexed in Pubmed: 27000426.

26. Vleggaar FP, Bij de Vaate EA, Valk GD, et al. Endoscopic ultrasoundguided ethanol ablation of a symptomatic sporadic insulinoma. Endoscopy. 2011; 43 Suppl 2 UCTN: E328-E329, doi: 10.1055/s-0030-1256775, indexed in Pubmed: 22020710.

27. Yang D, Inabnet WB, Sarpel U, et al. EUS-guided ethanol ablation of symptomatic pancreatic insulinomas. Gastrointest Endosc. 2015; 82(6): 1127, doi: 10.1016/i.gie.2015.06.030, indexed in Pubmed: 26232361.

28. Paik WH, Seo DW, Dhir V, et al. Safety and Efficacy of EUS-Guided Ethanol Ablation for Treating Small Solid Pancreatic Neoplasm. Medicine (Baltimore). 2016; 95(4): e2538, doi: 10.1097/MD.0000000000002538, indexed in Pubmed: 26825894.
29. Matsumoto $\mathrm{K}$, Kato $\mathrm{H}$, Tsutsumi $\mathrm{K}$, et al. Efficacy and Safety of Endoscopic Ultrasound-guided Ethanol Ablation Therapy for Pancreatic Neuroendocrine Tumors. Acta Med Okayama. 2016; 70(4): 313-316, indexed in Pubmed: 27549680.

30. Pai M, Habib N, Senturk H, et al. Endoscopic ultrasound guided radiofrequency ablation, for pancreatic cystic neoplasms and neuroendocrine tumors. World J Gastrointest Surg. 2015; 7(4): 52-59, doi: 10.4240/wigs. v7.i4.52, indexed in Pubmed: 25914783.

31. Armellini $\mathrm{E}$, Crinò $\mathrm{SF}$, Ballarè $\mathrm{M}$, et al. Endoscopic ultrasound-guided ethanol ablation of pancreatic neuroendocrine tumours: A case study and literature review. World J Gastrointest Endosc. 2016; 8(3): 192-197, doi: $10.4253 /$ wjge.v8.i3.192, indexed in Pubmed: 26862370.

32. Zhang WY, Li ZS, Jin ZD. Endoscopic ultrasound-guided ethanol ablation therapy for tumors. World J Gastroenterol. 2013; 19(22): 3397-3403, doi: 10.3748/wig.v19.i22.3397, indexed in Pubmed: 23801831.

33. Muscatiello N, Salcuni A, Macarini L, et al. Treatment of a pancreatic endocrine tumor by ethanol injection (PEI) guided by endoscopic ultrasound. Endoscopy. 2008; 40 Suppl 2: E83-E259, doi: 10.1055/s-2007995540, indexed in Pubmed: 18633893.

34. Mathers BW, Harvey HA, Dye CE, et al. Endoscopic ultrasound-guided ethanol ablation of a large metastatic carcinoid tumor: success with a note of caution. Endosc Int Open. 2014; 2(4): E256-E258, doi: 10.1055/s0034-1377612, indexed in Pubmed: 26135103.

35. Lakhtakia S. Complications of diagnostic and therapeutic Endoscopic Ultrasound. Best Pract Res Clin Gastroenterol. 2016; 30(5): 807-823, doi: 10.1016/j.bpg.2016.10.008, indexed in Pubmed: 27931638

36. Burghardt K, Kaemmerer D, Michael A, et al. Successful endoscopic ultrasound-guided ethanol ablation of a symptomatic sporadic insulinoma in a patient with severe comorbidities not suitable for pancreatic surgery. Diabetes Metab. 2017 [Epub ahead of print], doi: 10.1016/j. diabet.2016.12.012, indexed in Pubmed: 28161372.

37. Luo Y, Li Ji, Yang A, et al. 68Ga-Exendin-4 PET/CT in Evaluation of Endoscopic Ultrasound-Guided Ethanol Ablation of an Insulinoma. Clin Nucl Med. 2017; 42(4): 310-311, doi: 10.1097/RLU.0000000000001563, indexed in Pubmed: 28134698

38. Park DoH, Choi JH, Oh D, et al. Endoscopic ultrasonography-guided ethanol ablation for small pancreatic neuroendocrine tumors: results of a pilot study. Clin Endosc. 2015; 48(2): 158-164, doi: 10.5946/ ce.2015.48.2.158, indexed in Pubmed: 25844345 . 